\title{
Assessing HIV resistance in developing countries: Brazil as a case study
}

\author{
Maya L. Petersen, ${ }^{1}$ Marie-Claude Boily, ${ }^{2}$ and Francisco I. Bastos ${ }^{3}$
}

Suggested citation

Petersen ML, Boily MC, Bastos FI. Assessing HIV resistance in developing countries: Brazil as a case study. Rev Panam Salud Publica. 2006:19(3):146-56.

\begin{abstract}
Increased transmission of resistant HIV has been raised as a potential consequence of expanded access to antiretroviral therapy. We review how limitations in resources and health care infrastructure may impact the transmission of resistant HIV, and we examine data from Brazil as a case study. We introduce a biological and clinical framework to identify the major determinants of transmitted resistance and to discuss how these determinants may be affected by a lack of infrastructure. We then use our framework to examine HIV resistance data from Brazil. This country was chosen as a case study due to its extensive experience delivering antiretroviral drugs and because of the availability of data on the prevalence of resistant HIV there. The data from Brazil show that antiretroviral therapy can be delivered in a resource-limited setting without resulting in widespread transmission of resistant virus. While the Brazilian experience does not necessarily generalize to countries with less health care infrastructure, neither theory nor data support a foregone conclusion that resistance will necessarily dominate HIV epidemics in the developing world to a greater extent than it does in the developed world.
\end{abstract}

Key words HIV; anti-HIV agents; antiretroviral therapy, highly active; drug resistance, viral; developing countries; Brazil.

Antiretroviral therapy (ART) dramatically improves the prognosis and quality of life of people living with HIV / AIDS (1). However, these benefits remain unrealized for the majority of the world's HIV-infected individuals (2). There is a growing international consensus that increasing access to

1 University of California, Berkeley, School of Public Health, Division of Epidemiology, Berkeley, California, United States of America. Send correspondence to: Maya L. Petersen, e-mail: mayaliv@ gmail.com; 1351 Guerrero St., San Francisco, California 94110, United States of America; telephone: 415-225-5354.

2 Imperial College, Department of Infectious Diseases Epidemiology, London, United Kingdom.

3 Fundação Oswaldo Cruz (FIOCRUZ), Rio de Janeiro, Brasil.
ART in the developing world is both a moral and public health priority (3). Although providing ART will offer unquestioned benefit to the individual, there remains a concern that extensive distribution of therapy in poorly monitored situations will worsen the HIV epidemic as a result of the widespread emergence and dissemination of viral variants that are resistant to antiretroviral drugs (4-6).

Many authors concur that rapidly expanding access to ART in the developing world is crucial. They stress, however, that access must be accompanied by sufficient infrastructure to minimize the development of drug resis- tance (7-9). An extreme version of this viewpoint, taken by some authors (5, 6), is that ART access should not be expanded in the developing world until stringent conditions can be met. These authors emphasize that lower levels of adherence to prescribed drug regimens, an erratic drug supply, and limited on laboratory monitoring resulting from inadequate infrastructure will increase the rate at which resistant HIV evolves among treated individuals. These persons will then transmit resistant HIV to others, which could potentially lead to a reduction in or elimination of the benefits of expanded access for both individuals and society. 
In the debate surrounding the expansion of access to ART, it is commonly assumed that poor infrastructure will result in higher levels of drug-resistant HIV. However, evidence is emerging that infrastructure limitations may not accelerate the evolution of resistant virus among treated individuals to the extent anticipated. In addition, population levels of resistance are profoundly affected by multiple factors besides the rate at which resistance evolves among treated individuals. These other factors include the availability of first-line and salvage therapies and their effects on disease progression and infectivity, and the risk behaviors of treated and untreated HIV-infected individuals. Poor infrastructure may affect many of these factors, with unpredictable net effects on the population's level of resistance.

In this paper we summarize and clarify the understanding of the major factors that determine the proportion of newly infected individuals with resistant HIV infections. Some of these factors have been previously studied using mathematical models $(8,10,11)$. However, the complexity of both predicting and interpreting trends in population levels of ART resistance is not always appreciated in the larger debate surrounding expansion of access to ART in the developing world. Our goal is to provide a qualitative and intuitive understanding of the multiple epidemiological parameters that determine the population level of resistant HIV, and to examine ways in which health care infrastructure may affect these parameters. We present a theoretical framework to assist in the interpretation of existing resistance data and in the prediction of future trends in HIV resistance. Drawing on available data on the emergence and transmission of resistant HIV in Brazil, we then use this framework to examine the factors that may have contributed to current levels of resistant HIV in that country. We conclude by examining predictions about the consequences of expanded ART in the developing world, and we outline areas where data are urgently needed to inform these predictions.

\section{THEORETICAL FRAMEWORK: PARAMETERS DETERMINING THE LEVEL OF RESISTANCE}

The level of HIV resistance in a population can be quantified in at least two different ways: (1) the proportion of HIV infections among treatmentnaive individuals that are resistant, which reflects the transmission of resistant virus, and (2) the proportion of HIV infections among treated individuals with high plasma levels of resistant HIV RNA ("virologic failure"), which reflects the evolution of resistance in the treated population. Given current emphasis on the transmission of resistance, our discussion focuses primarily on the level of resistance in the newly infected, treatment-naive population.

The proportion of resistant infections among newly infected individuals depends on the prevalence of individuals infected with resistant virus and the prevalence of individuals infected with sensitive virus in the HIVinfected population, as well as the relative frequency with which these persons transmit HIV. In this section we outline the major parameters that determine the proportion of the prevalent HIV-infected population infected with resistant virus (Table 1). These parameters include: (1) rates of viral evolution in the presence and absence of antiretroviral treatment, (2) the coverage of ART among individuals infected with sensitive virus and among persons infected with resistant virus, and (3) the extent to which ART reduces plasma HIV RNA levels and slows disease progression (treatment efficacy) among individuals infected with sensitive virus and among persons infected with resistant virus. The proportion of resistant infections among newly infected individuals further depends both on the relative infectivity of persons infected with resistant virus as compared to individuals infected with sensitive virus and on the frequency of risk behavior in these two populations.

We discuss the hypothetical impact of each parameter on the proportion of resistant infections among newly infected individuals. In reality, the de- terminants of resistance are both more complex and more interrelated than presented here. The framework is presented as a tool to consider the major factors likely to affect the proportion of new HIV infections that are resistant. It should be noted that the discussion in this section is descriptive rather than prescriptive. By no means does identification of a change in drug coverage or efficacy as being likely to result in a decrease in the level of resistance recommend such a change as a public health intervention.

\section{Viral evolution}

HIV evolves rapidly due to its high replication and mutation rates (12). In individuals treated with ART, HIV experiences a continuing selective pressure to evolve resistance. In the absence of ART, resistant HIV is generally at a competitive disadvantage (exhibits lower "fitness") compared to wild-type virus. This is due to the fact that mutations that confer resistance often also reduce viral replicative capacity, and they may reduce the ability of the virus to infect $\mathrm{CD} 4^{+} \mathrm{T}$ cells. These secondary effects can be referred to as the "fitness costs" of resistance. Thus, strong evolutionary pressures exist in vivo, whereby drug-sensitive virus often outcompetes drug-resistant virus in the absence of drug pressure.

Evolution in both directions, towards increased resistance or towards increased sensitivity is accelerated by HIV's capacity for latency, with an infected individual retaining a latent reservoir of past viral quasispecies (12). An individual whose viral population has evolved resistance during treatment retains a latent population of sensitive virus in resting $\mathrm{CD}^{+} \mathrm{T}$ cells, monocytes, and macrophages (12). When treatment is interrupted, this sensitive virus can rapidly overgrow resistant virus and become the new dominant quasispecies $(13,14)$. However, if the same individual restarts therapy, latent, resistant virus regains a competitive advantage and regains dominance (13).

These issues of fitness and latency are highly relevant to studies aimed at 
TABLE 1. Potential impacts of decreased infrastructure on parameters determining prevalence of resistant HIV among newly infected individuals

\begin{tabular}{|c|c|c|}
\hline Parameter & Potential impact of decreased infrastructure & Effect on level of resistance \\
\hline $\begin{array}{l}\text { Evolution of viral resistance among treated } \\
\text { individuals }\end{array}$ & $\begin{array}{l}\text { Lower or inconsistent drug availability may result in treatment } \\
\text { interruptions. }\end{array}$ & Unclear \\
\hline \multirow[t]{2}{*}{$\begin{array}{l}\text { Coverage of first-line ART (initiation of } \\
\text { ART among individuals infected with } \\
\text { sensitive virus) }\end{array}$} & $\begin{array}{l}\text { Lower drug availability and diagnosis rates and/or more restrictive } \\
\text { treatment protocols may result in lower coverage. Lower coverage } \\
\text { will result in decreased selective pressure for the emergence of } \\
\text { resistance. }\end{array}$ & Less resistance \\
\hline & $\begin{array}{l}\text { Treatment initiation at later disease stage may result in less effective } \\
\text { viral suppression. }\end{array}$ & More resistance \\
\hline $\begin{array}{l}\text { Coverage of partial ART (initiation and } \\
\text { interruption of therapy with drugs to which } \\
\text { the virus that infects an individual is } \\
\text { resistant) }\end{array}$ & $\begin{array}{l}\text { Lack of laboratory monitoring may result in higher coverage of partial } \\
\text { ART (due to lack of awareness that patient is resistant to treatment). }\end{array}$ & More resistance \\
\hline $\begin{array}{l}\text { Coverage of salvage therapy (initiation and } \\
\text { interruption of therapy among individuals } \\
\text { infected with resistant virus using drugs to } \\
\text { which the virus remains sensitive) }\end{array}$ & $\begin{array}{l}\text { Fewer treatment options, less laboratory monitoring to identify } \\
\text { treatment failures, and lack of resistance tests to guide salvage drug } \\
\text { choices may result in lower coverage of salvage therapy. }\end{array}$ & $\begin{array}{l}\text { Unclear; depends on impacts of } \\
\text { salvage therapy on the mortality } \\
\text { and infectivity of individuals } \\
\text { infected with resistant virus }\end{array}$ \\
\hline \multirow{2}{*}{$\begin{array}{l}\text { Mortality of individuals infected with } \\
\text { sensitive virus relative to individuals } \\
\text { infected with resistant virus }\end{array}$} & $\begin{array}{l}\text { Lower first-line efficacy may result in increased mortality among } \\
\text { individuals infected with sensitive virus. }\end{array}$ & More resistance \\
\hline & $\begin{array}{l}\text { Lower salvage therapy efficacy may result in increased mortality } \\
\text { among individuals infected with resistant virus. }\end{array}$ & Less resistance \\
\hline
\end{tabular}

${ }^{\mathrm{a}} \mathrm{ART}=$ antiretroviral therapy.

defining the frequency of HIV transmission. Theoretically, given the significant fitness disadvantage associated with drug resistance, a person who is newly infected with a drugresistant variant will quickly lose measurable levels of this resistance. However, because individuals who are newly infected with drug-resistant HIV lack a large latent reservoir of wild-type HIV, this process of "reversion" requires back mutations rather than emergence of a preexisting virus. For reasons that remain unclear, back reversions appear to occur slowly, over months to years (15).

\section{ART coverage among individuals infected with sensitive virus}

First-line ART improves survival and well-being among individuals infected with sensitive virus, and thus potentially increases the period during which those persons can transmit sensitive virus. At the same time, the infectivity of most treated individuals infected with sensitive virus is likely to be low, as a result of viral suppression $(16,17)$. The magnitude of the effects of ART on infectivity and survival is determined by how effective treatment is at reducing plasma HIV RNA levels and slowing disease progression; we refer to these effects as "treatment efficacy." However, higher ART coverage among the population infected with sensitive HIV will likely increase the level of resistance since a larger number of individuals are at risk for developing resistance. 


\section{ART coverage among individuals infected with resistant virus (partial and salvage therapy)}

"Partial treatment" here refers to treatment with ART regimens to which the virus that infects an individual is resistant, permitting ongoing viral replication. Continuing ART in the presence of ongoing viral replication imposes a selection pressure that favors both the continued dominance of resistant virus and the accumulation of additional resistance mutations (12). Partial treatment may provide some degree of durable benefit, either due to continued partial activity of the drugs against the drug-resistant variant or due to the selective maintenance of a less fit and/or less virulent strain. In contrast, withdrawal from partial treatment allows for the reemergence of the more fit, drug-sensitive variant (18). Given the potential benefit of partially effective therapy compared to no therapy, many persons with limited options for complete viral suppression are maintained on treatment to which the HIV infecting them is resistant. Partial treatment may increase the potential transmission of resistant virus by providing two things: (1) selective pressure favoring the dominance of resistant viral quasispecies and (2) clinical benefits that increase survival and, potentially, sexual activity among individuals infected with resistant virus. There is some evidence, however, that the infectivity of partially treated individuals may be lower than that of untreated persons infected with sensitive virus $(18,19)$, possibly due to the fitness costs associated with resistance mutations and the lower plasma HIV RNA levels associated with partial treatment (14). Such an effect would mitigate the impact of partial therapy on the transmission of resistant virus.

"Salvage therapy" refers to the treatment of individuals infected with resistant virus using drugs to which the virus infecting them remains sensitive. Greater coverage of salvage therapy implies fewer untreated individuals harboring detectable levels of resistant HIV. In addition, a greater coverage of salvage therapy should, in theory, pro- vide individuals who acquired drugresistant HIV a greater opportunity for complete viral suppression. The impact that multiple options for salvage therapy have on the population level of resistance is not straightforward. Although treatment failure rates are considerably higher for salvage drug regimens than for initial treatment, second- and third-line drug regimens can produce durable decreases in plasma HIV RNA level (20), with presumptive accompanying decreases in infectivity. At the same time, salvage therapy provides a selective pressure for the accumulation of new resistance mutations, and, by improving the survival and well-being of persons infected with resistant virus, potentially increases their opportunity for transmission. As is the case with first-line ART, the magnitude of these effects on mortality and infectivity will depend on the efficacy of salvage therapy.

\section{HEALTH CARE INFRASTRUCTURE AND LEVEL OF RESISTANCE}

The parameters that determine the proportion of newly infected individuals who are infected with resistant virus may be influenced in a variety of ways by the level of available infrastructure. This includes the health care delivery systems in place to diagnose, monitor, and treat HIV, as well as the means by which antiretroviral drugs are procured and delivered to the point of care. We examine how infrastructure may differ as a result of resource limitations, and we use the biologic and clinical framework outlined above to discuss how differences in infrastructure may influence emergence and transmission of resistance (Table 1).

\section{Viral evolution}

Resource limitations and lack of infrastructure may result in use of poorquality drugs or drug regimens, thereby leading to incomplete virologic responses to treatment and higher levels of drug resistance. Sub- optimal treatment regimens, such as monotherapy or dual therapy, treatment with poor-quality antiretroviral drugs, suboptimal dosing, and poor absorption, may increase the rate at which viral resistance evolves among treated individuals (12). This risk forms the basis for much of the concern over the dangers of expanding access to ART. Additional data are needed to address the extent to which such infrastructure limitations will accelerate the emergence of antiretroviral resistance among treated patients.

There are several reasons to believe that poor delivery infrastructure may not result in increased resistance on the scale anticipated. First, mono and dual ART are likely to be used only rarely as ART programs are introduced in resource-limited settings. The most basic ART packages recommended by the World Health Organization (WHO), with the exception of programs to prevent vertical transmission, currently include triple therapy and standardized salvage regimens (2). In addition, ART in the developing world will in part be administered in fixed-dose combinations that include more than one drug class. This contrasts with the developed world, where ART was introduced over the course of many years, first as monotherapy and then as dual therapy. This provided ample opportunity for the emergence of resistant virus under suboptimal regimens. If anything, the exposure to suboptimal treatment regimens will be lower in resource-poor regions than was true for the resourcerich areas.

Poor delivery infrastructure and resource limitations may also result in interruptions in drug supply and intermittent availability of antiretroviral drugs. The impact of these interruptions on population levels of drug resistance are impossible to quantify. Treatment interruptions may increase the risk that viral resistance emerges $(21,22)$. However, if erratic drug supplies result in periods of complete virologic suppression, followed by absence of drug pressure, it is not clear that such a situation will favor the emergence of resistance. 
The scientific literature contains conflicting results with respect to the relationship between adherence to drug treatment and the evolution of resistance. Traditionally, poor adherence has been considered to increase the risk of resistance $(5,23)$. However, data are accumulating that HIV-infected individuals with poor adherence to ART are at a lower risk of developing resistance than are those with moderate adherence, possibly due to a lack of sufficient selective pressure exerted at low drug concentrations (24). Specifically, the relationships between adherence and resistance appear to be drugspecific $(24,25)$, with resistance to ritonavir-boosted protease inhibitor regimens emerging at a lower level of adherence than unboosted protease inhibitor regimens and non-nucleoside reverse transcriptase inhibitor regimens. This suggests that a nation's choice of first-line regimen may influence the impact of adherence on level of resistance. Finally, it is clear that resource limitations and poor infrastructure need not result in poor adherence (25-27).

\section{ART coverage among individuals infected with sensitive virus}

Resource limitations and lack of infrastructure may result in lower coverage of ART among individuals infected with sensitive virus. This can occur due to limited access to diagnosis and treatment services, limited availability of ART drugs, and/or treatment protocols that recommend more restrictive conditions for initiation of antiretroviral therapy. Limited infrastructure may mean that fewer individuals initiate treatment, and do so at later stages of disease. Delayed initiation of ART could lead to lower levels of complete viral suppression, given data suggesting that advanced immunodeficiency predicts a less robust response to treatment (12). In theory, this could lead to higher levels of drug resistance among the treated population and higher rates of drug-resistant HIV transmission. At the same time, late initiation of treatment will de- crease both the size of the population at risk for developing resistance and the duration for which individuals are treated, and thus their opportunity for developing and transmitting resistant virus.

\section{ART coverage among individuals infected with resistant virus (partial and salvage therapy)}

As discussed above, partial treatment has the potential to increase the level of resistance by simultaneously providing a selective pressure favoring resistant virus, failing to suppress plasma HIV RNA levels, prolonging survival, and improving health and well-being. All of these processes could lead to more opportunities for transmission of drug-resistant HIV.

Individuals may be treated with drugs to which the virus that infects them is resistant (partial treatment) either because resistance remains undetected or because alternative regimens are lacking and partial treatment is considered superior to no treatment. Infrastructure limitations that prevent adequate monitoring of treatment response using plasma HIV RNA level and $\mathrm{CD}^{+} \mathrm{T}$-cell count tests may result in a higher number of individuals who continue to receive partial therapy because their treatment failure has not been detected. However, several less resource-intensive, alternative approaches to monitoring treatment success are under study, and more are being researched $(28,29)$. This suggests that effective patient monitoring need not remain out of reach in the absence of laboratory capacity. At the same time, more limited drug availability or more restrictive eligibility requirements for continuing treatment may increase the proportion of persons infected with resistant virus who go untreated.

As with first-line therapy, it is possible that the coverage or efficacy of salvage regimens in other resourcelimited settings may be lower than in the developed world. This can happen due to fewer drug choices, lack of laboratory monitoring to allow the rapid diagnosis of virologic failure (thereby resulting in delayed time to a switch and more resistance at the time of the switch), lack of resistance testing to guide regimen designs at the time of the switch, and/or a shortage of welltrained health care providers. The impact of such differences on level of resistance will depend on relative effects of salvage therapy on mortality and infectivity, and it cannot be straightforwardly predicted.

\section{Risk behavior}

The risk behavior of HIV-infected individuals can be affected by counseling and prevention, both in the general population and in association with diagnosis and treatment. Effective treatment improves health and increases survival. Whether these changes will be reflected in increased transmission of HIV depends in part on whether ART delivery systems can effectively tie treatment to prevention, a goal that has been notoriously elusive in developed countries (30).

No broad generalization can be made about the likely effect of infrastructure limitations on risk behavior shifts, or how this effect might differ among the population infected with resistant virus as compared to the population infected with sensitive virus. There have been reports that risk behaviors have increased in developed countries after widespread use of ART, both in the HIV-positive and HIV-negative populations (30-32). However, the reports of this increase have not been consistent, and the factors that lead to increases in risk behavior remain incompletely understood $(30,33)$. It is likely that the impact of ART on risk behavior will vary among regions and cultures, and more research in developing-world settings is urgently needed.

\section{CASE STUDY: RESISTANT HIV IN BRAZIL}

In the following section the framework that we presented above is used to 
examine the antiretroviral delivery system in Brazil and to interpret the data on observed levels of resistance in the country. We chose Brazil as a case study because it is one of the few developing countries with substantial experience delivering ART and with data available on the prevalence of resistance. While ART remains rare or has only recently become available in most of the developing world, Brazil has provided universal access to ART since 1996. Brazil is also home to over a third of the individuals infected with HIV in the developing world who are currently receiving ART (34). In addition, Brazil has the technical capacity to make surveillance for antiretroviral resistance feasible. While these unique characteristics in Brazil may limit our ability to generalize our findings to all resource-poor areas, Brazil's successes serve to set desirable and achievable standards. Also, much of the infected population in Brazil is concentrated in large urban centers (35). Although the epidemic is increasingly affecting smaller municipalities and rural areas, the initial urban concentration has made some of the infrastructure barriers less of an issue in Brazil than they will be in areas such as subSaharan Africa.

\section{Brazil's antiretroviral delivery program}

Universal free access to antiretroviral medications has been guaranteed in Brazil by federal law since December 1995. Since the universal access program was introduced, the number of HIV-infected individuals in Brazil treated with ART has grown rapidly. In 2003, approximately 125000 of the estimated 600000 HIV-infected Brazilians were receiving ART $(36,37)$. National treatment guidelines state that all HIV-infected individuals with symptoms or with $\mathrm{CD}^{+} \mathrm{T}$-cell counts less than $200 \mathrm{~mm}^{3}$ should receive antiretroviral treatment, and those with $\mathrm{CD}^{+}{ }^{+} \mathrm{T}$-cell counts between 200 and 350 cells $/ \mathrm{mm}^{3}$ should be considered for treatment (38).

A national network exists in Brazil for tracking antiretroviral prescrip- tions. Antiretroviral medications can be dispensed only by federally accredited public clinics and hospitals. National networks are also used to evaluate plasma HIV RNA levels and CD4 ${ }^{+}$ T-cell counts. These networks have been implemented despite significant geographic disparities in the availability of infrastructure and resources (35). In addition, since 1999, several laboratories in Brazil have published findings on the prevalence of resistant HIV. Increasingly, these research laboratories are being integrated into national and international resistance surveillance networks.

\section{Level of drug resistance}

Table 2 reviews the studies reporting the prevalence of primary resistance mutations in Brazil. Prevalence of accessory or secondary mutations, some of which occur as natural polymorphisms in non-subtype B virus, are not reported. The table presents data on the prevalence of resistance in two groups: (1) ART-naive patients and (2) patients treated with ART, defined as including at least three drugs and at least one protease inhibitor or non-nucleotide reverse transcriptase inhibitor.

The prevalence of resistance is high among patients failing ART in Brazil, according to both published articles (39-41) and unpublished studies. ${ }^{4}$ These findings for Brazil are consistent with the ones that have been seen in the developed world (42). Indeed, less than a decade after the introduction of combination antiretroviral therapy, an estimated $76 \%$ of patients who are receiving ART in the United States of America carry HIV strains that are resistant to one or more antiretroviral drugs (42).

The majority of studies that evaluate resistance in the treatment-naive before widespread availability of potent antiretroviral drugs in Brazil (that is, prior to 1997) report a low prevalence of re-

\footnotetext{
4 Hart S, Shafer R, Tanuri A, Soares M, Brun-Vezinet F, Grossman Z, et al. Global mapping of HIV-1 drug resistance patterns [abstract]. 10th Conference on Retroviruses and Opportunistic Diseases, Boston, 2003.
}

sistance to all drug classes (43). 5, 6 A single study (44) reported a relatively high prevalence $(33 \%)$ of resistance to nucleoside reverse transcriptase inhibitors among antiretroviral-naive patients prior to the widespread introduction of ART; the significance of this finding is unclear. More recent studies suggest that transmitted resistance has increased in Brazil since ART became widely available, according to published research $(39,45-48)$ and unpublished studies. ${ }^{4} 7$ The level of transmitted resistance in Brazil remains comparable to that observed in Europe and the United States, where resistant strains infect up to $20 \%$ of drug-naive individuals $(49,50)$.

\section{Understanding resistance in Brazil}

Evolution of viral resistance. Brazil has succeeded in developing a highquality nationwide drug delivery infrastructure. Brazil's domestic drug manufacturing program and differential pricing agreements with pharmaceutical companies have helped to ensure a constant supply of high-quality drugs (35). Reports on the success of the Brazilian infrastructure in maintaining high levels of adherence differ, with estimates ranging from less than $50 \%$ to over $80 \%$ of participants on ART achieving regular or optimal adherence (defined slightly differently in the various studies), a level comparable to that observed in developed countries (51-54). Monotherapy and dual therapy in Brazil have decreased steadily over the years since ART became available, and are currently not prescribed for any new patients (38).

\footnotetext{
5 Barreto CC, Saez-Alquezar A, Stuyver L, Dias RS, Sabino EC. Prevalence of mutations that confer resistance to reverse transcriptase (RT) and protease (PR) inhibitors among drug naive HIV-1 positive blood donors [abstract]. Rev Inst Med Trop São Paulo. 1999;41(Suppl 11):S35.

6 Leal ES, Filho DS, Machado D, Castelo A, Dias R, Pannuti $C$, et al. Mutations associated with drug resistance in a population of drug naive HIV-1 infected individuals [abstract]. Rev Inst Med Trop São Paulo. 1999;41(Suppl 11):S48.

7 Tanuri A, Soares MA, Brindeiro RM, Diaz RS, Costa LJ, Sabino EC, et al. Brazilian network for drug resistance surveillance: results from the first national survey [abstract]. XIV International AIDS Conference, Barcelona, 2002.
} 
TABLE 2. Studies of antiretroviral resistance in Brazil among patients treated with antiretroviral therapy (ART) and among ART-naive patients

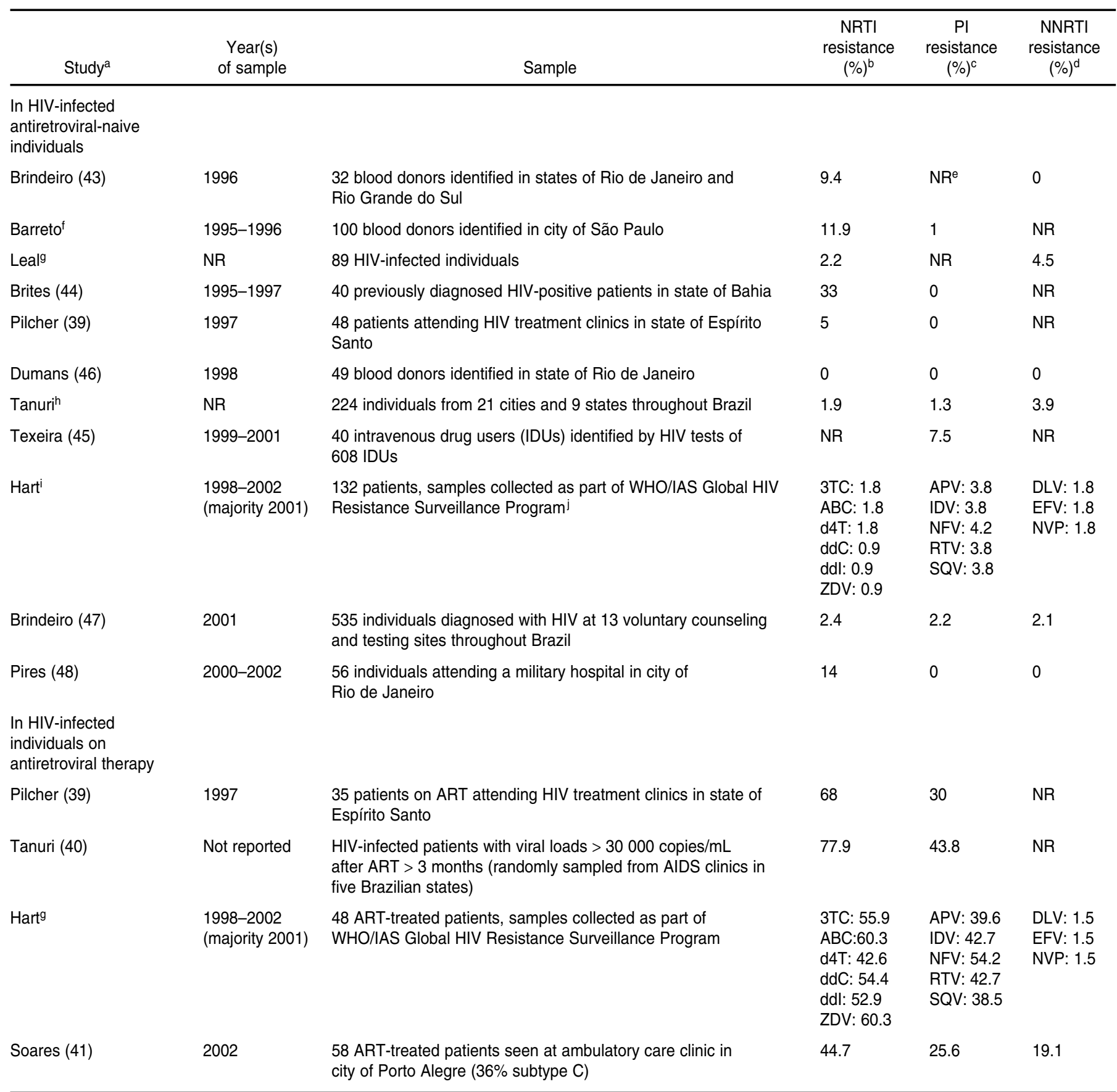

a References provided in parentheses, except in the case of abstracts.

${ }^{b} \mathrm{NRTI}=$ nucleoside reverse transcriptase inhibitor.

${ }^{\mathrm{c}} \mathrm{PI}=$ protease inhibitor.

d $\mathrm{NNRTI}=$ non-nucleoside reverse transcriptase inhibitor.

e $\mathrm{NR}=$ not reported

${ }^{f}$ Barreto CC, Saez-Alquezar A, Stuyver L, Dias RS, Sabino EC. Prevalence of mutations that confer resistance to reverse transcriptase (RT) and protease (PR) inhibitors among drug naive HIV-1 positive blood donors [abstract]. Rev Inst Med Trop São Paulo. 1999;41(Suppl 11):S35

${ }^{9}$ Leal ES, Filho DS, Machado D, Castelo A, Dias R, Pannuti C, et al. Mutations associated with drug resistance in a population of drug naive HIV-1 infected individuals [abstract]. Rev Inst Med Trop São Paulo. 1999;41(Suppl 11):S48

h Tanuri A, Soares MA, Brindeiro RM, Diaz RS, Costa LJ, Sabino EC, et al. Brazilian network for drug resistance surveillance: results from the first national survey [abstract]. XIV International AIDS Conference, Barcelona, Spain, 2002.

i Hart S, Shafer R, Tanuri A, Soares M, Brun-Vezinet F, Grossman Z, et al. Global mapping of HIV-1 drug resistance patterns [abstract]. 10th Conference on Retroviruses and Opportunistic Diseases, Boston, Massachusetts, United States, 2003.

j The drugs listed are: $3 T C=$ lamivudine, $A B C=$ abacavir, $d 4 T=$ stavudine, ddC = zalcitabine, ddl = didanosine, ZDV = zidovudine, APV = amprenavir, IDV = indinavir, NFV = nelfinavir, RTV = ritonavir, SQV = saquinavir, DLV = delavirdine, EFV = efavirenz, NVP = nevirapine. 
These factors have likely limited the rate at which resistance evolves among the treated population.

ART coverage among individuals infected with sensitive virus. In Brazil, ART is free for all who need it. In 2003 an estimated $78 \%$ of adults in Brazil who were in need of antiretroviral care were receiving it, a coverage rate comparable to that in North America and parts of Europe (55). Although treatment protocols during the early days of the epidemic in Brazil differed from those in the developed world, current Brazilian protocols that indicate when to initiate treatment are similar to those used in the United Kingdom. This suggests that the relatively low resistance levels observed in Brazil cannot be explained, at least in recent years, by low ART coverage.

Coverage of partial and salvage ART. In Brazil the range of salvage therapies available is comparable to that available in the United States (38). No data are available on use of partial therapies or the delay in changing therapies once resistance develops. However, the development of nationwide laboratory capacity has made monitoring of treatment success feasible. The availability of salvage drug regimens, combined with regular plasma HIV RNA level testing, suggests that the amount of time spent on partial therapy is unlikely to be significantly longer in Brazil than it is in Europe and the United States.

Few data are available regarding the impact of ART in Brazil on mortality rates and infectivity among individuals infected with resistant virus as compared to individuals infected with sensitive virus. In addition, very little is known about risk behaviors among treated individuals in Brazil, and how those risk behaviors may differ between individuals infected with resistant virus as compared to persons infected with sensitive virus. Improved data on these parameters would inform predictions of whether the level of transmitted resistance in Brazil is likely to remain low as coverage increases.

\section{SHOULD GLOBAL ACCESS TO ANTIRETROVIRAL THERAPY BE EXPANDED?}

The available data show that resistance has not yet become a greater problem in Brazil than in richer countries. Using our analytical framework, our appraisal suggests that it is unfounded to assume that resource and infrastructure limitations will necessarily lead to an increase in resistance. In Brazil it is possible to identify some of the major factors that have likely contributed to the relatively low levels of transmitted resistance that have been seen. However, direct extrapolations to other developing countries, or even to the future of Brazil itself, are difficult without additional data.

Some of the data needed to accurately predict trends in resistance are biological. How quickly does sensitive virus replace resistant virus as the dominant viral quasispecies when treatment is interrupted? How does resistance affect the virus's pathogenicity and infectivity? At what level of adherence is the risk of developing resistance greatest? How do these parameters vary depending on antiretroviral drug and drug class?

However, many of the data needed to accurately predict the impact of resource limitations on trends in drug resistance are contextual. How does ART access affect risk behaviors among treated and untreated individuals? How well are individuals able to adhere to their drug regimens? To what extent will alternatives to plasma HIV RNA level monitoring delay transition off of partial treatment? Brazil, which is generally considered a middle-income country, has a much stronger health care infrastructure than do many nations with more limited resources, such as the majority of the countries of subSaharan Africa. Therefore, it may not be possible to generalize the Brazilian experience to countries with lower incomes. However, the per capita health care budget in Brazil is much smaller than in such countries as Canada and the United States, and the distribution of income in Brazil is one of the most unequal in the world. Given these re- source constraints, Brazil's achievements in implementing an ART procurement, delivery, and monitoring system and in limiting the spread of resistant HIV are encouraging. Brazil's experience demonstrates that it is not possible to take for granted that resistance will dominate HIV epidemics in the developing world to a greater extent than in the developed world. Considerable context-specific data are needed before strong pessimistic or optimistic predictions about future trends in the prevalence and impact of resistant HIV can be made for any given country or for any given regimen.

In the absence of data to make reliable predictions regarding the impact of expanded access on the spread of resistant HIV in the developing world, use of a double standard in judgments about the appropriateness of ART access in the developed world as compared to ART access in the developing world cannot be justified. In highincome countries, ART was used widely before any data on viral resistance were available, and its continued use is not debated, despite high rates of resistance. Brazil has demonstrated that it is possible for middle-income countries to reach the standards of ART care achieved in the developed world. Other developing countries have the opportunity to follow this example and to benefit from the experience both of Brazil and of developed nations as ART is introduced to populations without prior treatment history.

The level of resistance observed among newly infected individuals is sometimes considered an indicator of the success of an antiretroviral delivery system. High levels of resistance among newly infected persons may be interpreted as evidence of failure to provide high-quality care, while low levels of resistance may be interpreted as evidence of a well-functioning system. However, the framework that we have presented highlights that the results of drug resistance surveillance must be interpreted with caution, whether comparing nations or trends within a nation.

Low levels of resistance should not be cause for complacency. Consider 
the case of a nation that treats only a small portion of its HIV-infected individuals and initiates therapy too late in the course of disease to significantly improve health and survival or to allow for the development of resistance. That nation could have a very low level of resistance, but also a minimal impact on HIV transmission and the burden of HIV disease. Similarly, an increasing level of resistance should not be used to argue that a system is functioning poorly, or that access should be scaled back until infrastructure can be improved. A country that improves its care for individuals infected with resistant HIV could see an increase in the population level of resistance, despite net decreases in HIV morbidity and mortality. The level of resistance achieved by an antiretroviral delivery system must be weighed against the system's success in achieving the additional goals of decreased mortality, morbidity, and disease incidence.

To maximize the benefits of ART, consensus is clear that access to drugs should be combined with development of infrastructure and provision of prevention services. Resistance undermines individual health and survival; efforts to minimize the emergence of resistance among treated individuals are a key aspect of providing quality care. The debate continues, however, over whether access to antiretroviral drugs should be delayed in areas where the current infrastructure is not considered adequate. The current understanding of viral resistance does not provide grounds for justifying such a delay. Providing antiretroviral therapy now to the millions who need it will both save lives and prevent suffering.

Acknowledgments. Maya Petersen is supported by a predoctoral fellowship from the Howard Hughes Medical Institute. Francisco I. Bastos is supported by Oswaldo Cruz Foundation PAPES grant 250.250.122 and a Brazilian Research Council (CNPq) salary grant.

\section{REFERENCES}

1. Detels R, Muñoz A, McFarlane G, Kingsley LA, Margolick JB, Giorgi J, et al. Effectiveness of potent antiretroviral therapy on time to AIDS and death in men with known HIV infection duration. Multicenter AIDS Cohort Study Investigators. JAMA. 1998;280(17):1497-503.

2. World Health Organization. Scaling up antiretroviral therapy in resource limited settings: guidelines for a public health approach. Geneva: WHO; 2004.

3. United Nations General Assembly. Special Session on HIV/AIDS. Declaration of commitment on HIV/AIDS. New York; U.N.: 2001. ( Resolution S-26/2).

4. Harries AD, Nyangulu DS, Hargreaves NJ, Kaluwa O, Salaniponi FM. Preventing antiretroviral anarchy in sub-Saharan Africa. Lancet. 2001;358(9279):410-4.

5. Popp D, Fisher JD. First, do no harm: a call for emphasizing adherence and HIV prevention interventions in active antiretroviral therapy programs in the developing world. AIDS. 2002;16(4):676-8.

6. Wadman M. Experts clash over impact of cheap AIDS drugs in Africa. Nature. 2001;410(6829):615-6.

7. Petrella M, Brenner B, Loemba H, Wainberg MA. HIV drug resistance and implications for the introduction of antiretroviral therapy in resource-poor countries. Drug Resist Updat. 2001;4(6):339-46.

8. Garnett GP, Bartley L, Grassly NC, Anderson RM. Antiretroviral therapy to treat and prevent HIV/AIDS in resource-poor settings. Nat Med. 2002;8(7):651-4.

9. Van der Groen G. The urgent need for feasibility studies of antiretroviral treatment in HIV-infected individuals in resourcelimited settings. AIDS. 2001;15(17):2342-4.
10. Blower SM, Gershengorn HB, Grant RM. A tale of two futures: HIV and antiretroviral therapy in San Francisco. Science. 2000;287(5453):650-4.

11. Blower SM, Aschenbach AN, Gershengorn HB, Kahn JO. Predicting the unpredictable: transmission of drug-resistant HIV. Nat Med. 2001;7(9):1016-20.

12. Deeks SG. Treatment of antiretroviraldrug-resistant HIV-1 infection. Lancet. 2003;362(9400):2002-11.

13. Albrecht D, Zollner B, Feucht HH, Lorenzen T, Laufs R, Stoehr A, et al. Reappearance of HIV multidrug-resistance in plasma and circulating lymphocytes after reintroduction of antiretroviral therapy. J Clin Virol. 2002;24(1-2):93-8.

14. Deeks SG, Wrin T, Liegler T, Hoh R, Hayden M, Barbour JD, et al. Virologic and immunologic consequences of discontinuing combination antiretroviral-drug therapy in HIV-infected patients with detectable viremia. N Engl J Med. 2001; 344(7):472-80.

15. Yerly S, Rakik A, De Loes SK, Hirschel B, Descamps D, Brun-Vezinet F, et al. Switch to unusual amino acids at codon 215 of the human immunodeficiency virus type 1 reverse transcriptase gene in seroconvertors infected with zidovudine-resistant variants. J Virol. 1998;72(5):3520-3.

16. Quinn TC, Wawer MJ, Sewankambo N, Serwadda D, Li C, Wabwire-Mangen F, et al. Viral load and heterosexual transmission of human immunodeficiency virus type 1. Rakai Project Study Group. N Engl J Med. 2000;342(13):921-9.

17. Barroso PF, Schechter M, Gupta P, Bressan C, Bomfim A, Harrison LH. Adherence to antiretroviral therapy and persis- tence of HIV RNA in semen. J Acquir Immune Defic Syndr. 2003;32(4):435-40.

18. Leigh Brown AJ, Frost SD, Mathews WC, Dawson K, Hellmann NS, Daar ES, et al. Transmission fitness of drug-resistant human immunodeficiency virus and the prevalence of resistance in the antiretroviral-treated population. J Infect Dis. 2003;187(4):683-6.

19. Yerly S, Jost S, Telenti A, Flepp M, Kaiser $\mathrm{L}$, Chave JP, et al. Infrequent transmission of HIV-1 drug-resistant variants. Antivir Ther. 2004;9(3):375-84.

20. Deeks SG, Hellmann NS, Grant RM, Parkin NT, Petropoulos CJ, Becker M, et al. Novel four-drug salvage treatment regimens after failure of a human immunodeficiency virus type 1 protease inhibitor-containing regimen: antiviral activity and correlation of baseline phenotypic drug susceptibility with virologic outcome. J Infect Dis. 1999;179(6):1375-81.

21. Yerly S, Fagard C, Gunthard HF, Hirschel B, Perrin L. Drug resistance mutations during structured treatment interruptions. Antivir Ther. 2003;8(5):411-5.

22. Martinez-Picado J, Morales-Lopetegi K, Wrin T, Prado JG, Frost SD, Petropoulos CJ, et al. Selection of drug-resistant HIV-1 mutants in response to repeated structured treatment interruptions. AIDS. 2002;16(6):895-9.

23. Montaner JS, Reiss P, Cooper D, Vella $S$, Harris M, Conway B, et al. A randomized, double-blind trial comparing combinations of nevirapine, didanosine, and zidovudine for HIV-infected patients: the INCAS Trial. Italy, The Netherlands, Canada and Australia Study. JAMA. 1998; 279(12):930-7. 
24. Bangsberg DR, Moss AR, Deeks SG. Paradoxes of adherence and drug resistance to HIV antiretroviral therapy. J Antimicrob Chemother. 2004;53(5):696-9.

25. Liechty CA, Bangsberg DR. Doubts about DOT: antiretroviral therapy for resourcepoor countries. AIDS. 2003;17(9):1383-7.

26. Orrell C, Bangsberg DR, Badri M, Wood $\mathrm{R}$. Adherence is not a barrier to successful antiretroviral therapy in South Africa. AIDS. 2003;17(9):1369-75.

27. Laurent C, Diakhate N, Gueye NF, Toure MA, Sow PS, Faye MA, et al. The Senegalese government's highly active antiretroviral therapy initiative: an 18-month follow-up study. AIDS. 2002;16(10): 136370.

28. Balakrishnan $P$, Dunne $M$, Kumarasamy N, Crowe S, Subbulakshmi G, Ganesh $\mathrm{AK}$, et al. An inexpensive, simple, and manual method of CD4 T-cell quantitation in HIV-infected individuals for use in developing countries. J Acquir Immune Defic Syndr. 2004;36(5):1006-10.

29. Kumarasamy N, Flanigan TP, Mahajan $\mathrm{AP}$, Carpenter CC, Mayer KH, Solomon S. Monitoring HIV treatment in the developing world. Lancet Infect Dis. 2002;2(11): 656-7.

30. Stolte IG, Coutinho RA. Risk behaviour and sexually transmitted diseases are on the rise in gay men, but what is happening with HIV? Curr Opin Infect Dis. 2002; 15(1):37-41.

31. Dukers NH, Goudsmit J, de Wit JB, Prins M, Weverling GJ, Coutinho RA. Sexual risk behaviour relates to the virological and immunological improvements during highly active antiretroviral therapy in HIV-1 infection. AIDS. 2001;15(3):36978.

32. Van de Ven P, Prestage G, Crawford J, Grulich A, Kippax S. Sexual risk behaviour increases and is associated with HIV optimism among HIV-negative and HIVpositive gay men in Sydney over the 4 year period to February 2000. AIDS. 2000; 14(18):2951-3.

33. Boily MC, Bastos FI, Desai K, Masse B. Changes in the transmission dynamics of the HIV epidemic after the wide-scale use of antiretroviral therapy could explain increases in sexually transmitted infections: results from mathematical models. Sex Transm Dis. 2004;31(2):100-13.

34. Teixeira PR, Vitoria MA, Barcarolo J. Antiretroviral treatment in resource-poor settings: the Brazilian experience. AIDS. 2004;18(Suppl 3):S5-7.

35. Bastos FI, Kerrigan D, Malta M, Carneiro da Cunha C, Strathdee SA. Treatment for HIV/AIDS in Brazil: strengths, challenges, and opportunities for operations research. AIDScience [online serial]. 2001;
1(15). Available from http://www.AID Science.com. Accessed 6 February 2005.

36. Brasil, Ministério de Saúde. Programa Nacional de DST e Aids. Dados e pesquisas em DST e Aids [Internet site]. Available from: http://www.aids.gov.br/. Accessed 6 February 2005.

37. Szwarcwald CL, Felga de Carvalho M. Estimativa do número de indivíduos de 15 a 49 anos infectados pelo HIV, Brasil, 2000. Bol Epidemiol AIDS. 2001;14(1). Available from: http://www.aids.gov.br/final/ biblioteca/bol htm/boletim.htm [Internet site]. Accessed 6 February 2005.

38. Brasil, Ministério de Saúde, Secretaria de Vigilância em Saúde, Programa Nacional de DST e Aids. Recomendações para terapia anti-retroviral em adultos e adolescentes infectados pelo HIV 2004. Brasília: MS; 2004.

39. Pilcher CD, Perkins MD, Fiscus SA, Johnston DM, Dietze R, Duque UH, et al. Genotypic resistance and the treatment of HIV-1 infection in Espírito Santo, Brazil. J Infect Dis. 1999;179(5):1259-63.

40. Tanuri A, Caridea E, Dantas MC, Morgado MG, Mello DL, Borges $S$, et al. Prevalence of mutations related to HIV-1 antiretroviral resistance in Brazilian patients failing HAART. J Clin Virol. 2002; 25(1):39-46.

41. Soares EA, Santos RP, Pellegrini JA, Sprinz E, Tanuri A, Soares MA. Epidemiologic and molecular characterization of human immunodeficiency virus type 1 in southern Brazil. J Acquir Immune Defic Syndr. 2003;34(5):520-6.

42. Richman DD, Morton SC, Wrin T, Hellmann N, Berry S, Shapiro MF, et al. The prevalence of antiretroviral drug resistance in the United States. AIDS. 2004 18(10):1393-401.

43. Brindeiro R, Vanderborght B, Caride E, Correa L, Oravec RM, Berro O, et al. Sequence diversity of the reverse transcriptase of human immunodeficiency virus type 1 from untreated Brazilian individuals. Antimicrob Agents Chemother. 1999; 43(7):1674-80

44. Brites C, Bahia F, Gilbert M, Pedroso C, Badaro R. Evaluation of viral resistance to reverse transcriptase inhibitors (RTI) in HIV-1-infected patients before and after 6 months of single or double antiretroviral therapy. Braz J Infect Dis. 2001; 5(4):177-82.

45. Teixeira SLM, Bastos FI, Hacker MA, Guimarães ML, Morgado MG. Trends in drug resistance mutations in antiretroviralnaive intravenous drug users of Rio de Janeiro. J Clin Virol. Forthcoming 2006.

46. Dumans AT, Soares MA, Pieniazek D, Kalish ML, De Vroey V, Hertogs K, et al. Prevalence of protease and reverse tran- scriptase drug resistance mutations over time in drug-naive human immunodeficiency virus type 1-positive individuals in Rio de Janeiro, Brazil. Antimicrob Agents Chemother. 2002;46(9):3075-9.

47. Brindeiro RM, Diaz RS, Sabino EC, Morgado MG, Pires IL, Brigido L, et al. Brazilian Network for HIV Drug Resistance Surveillance (HIV-BResNet): a survey of chronically infected individuals. AIDS. 2003;17(7):1063-9.

48. Pires IL, Soares MA, Speranza FA, Ishii SK, Vieira MC, Gouvea MI, et al. Prevalence of human immunodeficiency virus drug resistance mutations and subtypes in drug-naive, infected individuals in the Army Health Service of Rio de Janeiro, Brazil. J Clin Microbiol. 2004;42(1):426-30.

49. Little SJ, Holte S, Routy JP, Daar ES, Markowitz M, Collier AC, et al. Antiretroviral-drug resistance among patients recently infected with HIV. N Engl J Med. 2002;347(6):385-94.

50. Grant RM, Hecht FM, Warmerdam M, Liu L, Liegler T, Petropoulos CJ, et al. Time trends in primary HIV-1 drug resistance among recently infected persons. JAMA. 2002;288(2):181-8.

51. Brigido LF, Rodrigues $R$, Casseb J Oliveira D, Rossetti M, Menezes P, et al. Impact of adherence to antiretroviral therapy in HIV-1-infected patients at a university public service in Brazil. AIDS Patient Care STDS. 2001;15(11):587-93.

52. Pinheiro CA, de-Carvalho-Leite JC, Drachler ML, Silveira VL. Factors associated with adherence to antiretroviral therapy in HIV/AIDS patients: a crosssectional study in Southern Brazil. Braz J Med Biol Res. 2002;35(10):1173-81.

53. Remien RH, Bastos FI, Berkman A, Terto V, Raxach JC, Parker RG. Universal access to antiretroviral therapy may be the best approach to 'Do no harm' in developing countries: the Brazilian experience. AIDS. 2003;17(5):786-7.

54. Nemes MI, Carvalho HB, Souza MF. Antiretroviral therapy adherence in Brazil. AIDS. 2004;18(Suppl 3):S15-20.

55. World Health Organization/United Nations Programme on HIV/AIDS. Epidemiological fact sheet on HIV / AIDS and sexually transmitted infections. 2004 update. Brazil. Available from: http:// www.who.int/hiv/pub/epidemiology/ pubfacts/en/ [Internet site]. Accessed 6 February 2005.

Manuscript received 2 March 2005. Article accepted for publication 3 August 2005. 
RESUMEN Se ha especulado que el aumento de cepas del virus de la inmunodeficiencia humana (VIH) resistentes a medicamentos podría ser el resultado de un mayor acceso al tratamiento con antirretrovíricos. Tomando como ejemplo datos propios del Brasil, en

\section{El cálculo de la resistencia medicamentosa del VIH en países en desarrollo: el caso del Brasil}

Palabras clave este trabajo examinamos la manera en que la escasez de recursos y las carencias de la infraestructura sanitaria podrían estar influyendo en la transmisión de cepas resistentes de VIH. Empleamos un marco biológico y clínico para identificar los principales factores determinantes del aumento de la resistencia y exploramos la forma en que dichos factores podrían verse afectados por la falta de infraestructura. Posteriormente empleamos ese mismo marco para examinar las cifras de resistencia del Brasil, país que se eligió como ejemplo porque en él los medicamentos antirretrovíricos han tenido amplia distribución y porque hay abundantes datos acerca de la prevalencia de cepas de VIH en el territorio nacional. Las cifras del Brasil demuestran que se puede administrar el tratamiento con antirretrovíricos en lugares donde hay pocos recursos sin que ello provoque la transmisión generalizada de cepas víricas resistentes. Aunque la experiencia brasileña no necesariamente se puede proyectar a países con menos infraestructura sanitaria, no hay ningún esquema teórico ni datos que respalden la conclusión a priori de que en el mundo en desarrollo la epidemia de VIH transcurrirá con mayores cifras de resistencia que en países desarrollados.

$\mathrm{VIH}$, agentes anti VIH, terapia antirretroviral altamente activa, resistencia viral a drogas, países en desarrollo, Brasil.

\section{EI VIH/SIDA en países de América Latina Los retos futuros}

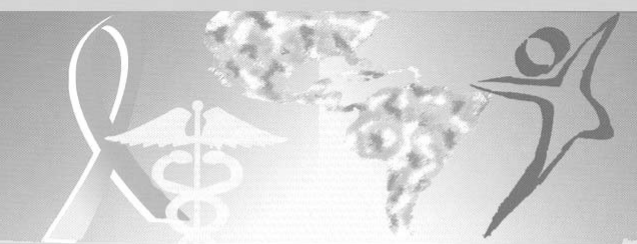

Este libro presenta información reciente y actualizada acerca de la magnitud y tendencias de la epidemia de VIH/SIDA en América Latina. En esta obra se evalúa la capacidad actual de vigilancia en los países, se examinan las respuestas nacionales del sector de la salud a la epidemia en cada país, se identifican las áreas fundamentales en las que se requieren con urgencia intervenciones específicas y se describen los retos futuros.

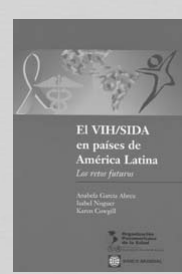

$2004 \cdot x i 316$ pp. • ISBN 9275315973 Código: PC $597 \cdot$ Precios: US $\$ 26.00$ en América Latina y el Caribe/ US $\$ 20.00$ fuera de América Latina

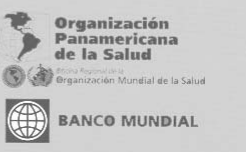

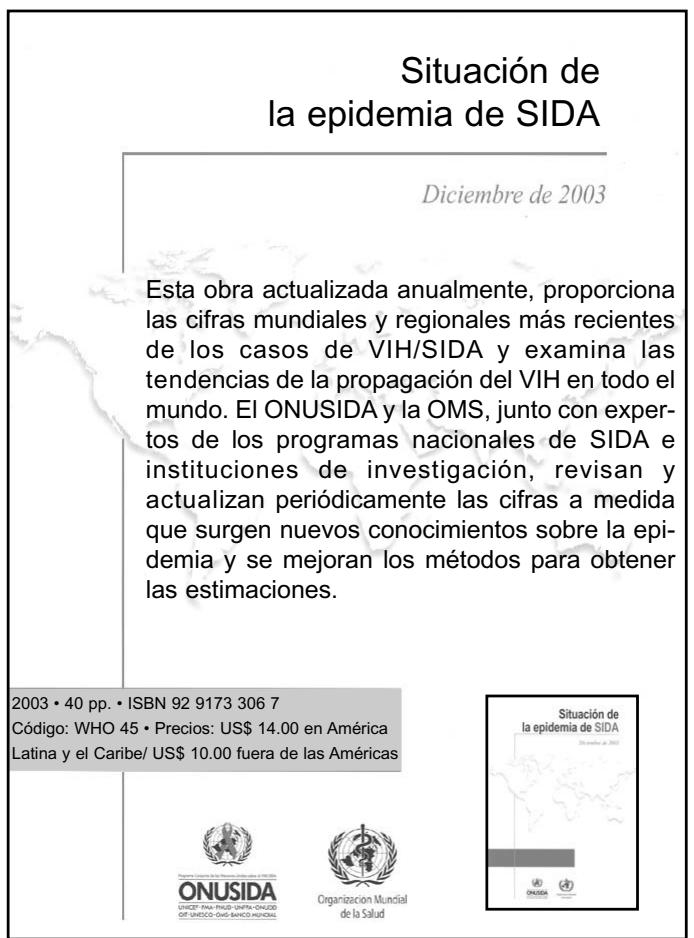

Esta obra actualizada anualmente, proporciona cifras mundiales y regionales mas recientes de los casos de VIH/SIDA y examina las de la propagación del VIH en todo e mundo. EI ONUSIDA y la OMS, junto con exper(afras a medida cimientos sobre la epitos métodos para obtener

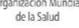
. . 